Edited by:

Ian Michiel Otto • Maurice V. Polak • Jianfu Chen • Yuwen Li

\section{Law-Making in the People's Republic of China}




\section{TABLE OF CONTENTS}

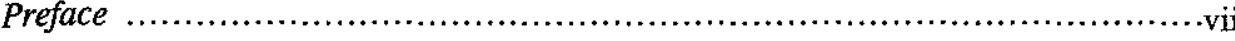

Table Of Contributors ....................

Abbreviations...

Part I: Overview and Review

An Overview of Law-Making in China …..................................... Jan Michiel Otto and Yuwen $\mathrm{Li}$

II Coming Full Circle: Law-Making in the PRC from a Historical Perspective ... 19 Jianfu Chen

Published by Kluwer Law International, P.O. Box 85889, $2508 \mathrm{CN}$ The Hague, The Netherlands. Sold and distributed in North, Central and South America by Kluwer Law International, 675 Massachusetts Avenue, Cambridge, MA 02139, U.S.A.

In all other countries, sold and distributed

by Kluwer Law International, Distribution Centre,
P.O. Box 322, 3300 AH Dordrecht, The Netherlands.

\section{Printed on acid-free paper \\ Cover design by Alfred Birnie bNO}

All Rights Reserved

(C) 2000 Kluwer Law International

Kluwer Law International incorporates the publishing programmes of

Graham \& Trotman Ltd, Kluwer Law and Taxation Publishers,

and Martinus Nijhoff Publishers.

No part of the material protected by this copyright notice may be reproduced or

utilized in any form or by any means, electronic or mechanical,

including photocopying, recording, or by any information storage and

retrieval system, without written permission from the copyright owner.

Printed in the Netherlands

III Ideology and Law-Making...

Harro von Senger

IV Socialist Law, Civil Law, Common Law, and the Classification of Contemporary Chinese Law....

Albert H.Y. Chen

\section{Part II: Institutions and Actors}

V The National People's Congress and the Making of National Law ..............75 Perry Keller

VI The State Council and Law-Making ......................................... 91

Li Shishi

VII Departmental Rule-Making in the People's Republic of China ................. 105

Chaoyang Jiang

VIII Local Law-Making in China - A Case Study of Shanghai

Sun Chao

IX Legislation in National Autonomous Areas

in the People's Republic of China

Shi Wenzheng and Bu Xiaolin

$X \quad$ Public Participation in Law-Making in the PRC

Zhu Jingwen

XI Explanations on the Proposed Law on Law-Making

of the People's Republic of China.

Li Buyun

\section{Part III: Case Studies}

XII Administrative Law-Making in the People's Republic of China

Jean-Pierre Cabestan

XIII Law-Making in the People's Republic of China: The Case of Contracts ...... 189

Pitman B. Potter 
XIV The Development of Criminal Law in the PRC

since the Institution of the Reform and Opening Up Policy ................... 205 Ye Feng

Part IV: Conclusion

XV Conclusion: A Comparativist's Outlook on Law-Making in China

Jan Michiel Otto

Appendices

Appendix 1 Unanswered Questions and Unresolved Issues:

Comments on the Law on Law-Making

Appendix 2 Law of the People's Republic of China on Law-Making........... 257

Selected Bibliography ............................................................. 281

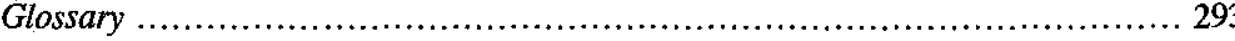




\title{
CONCLUSION: A COMPARATIVIST'S OUTLOOK ON LAW-MAKING IN CHINA
}

\author{
Jan Michiel Otto*
}

1 Theories of Comparative Law, and the Images of the Marble Boat, the Turtle and the Dragon

Attempting to draw conclusions on the basis of the preceding chapters is a daring and difficult task. Being a scholar trained in law and administration in developing countries, I have decided to deal with it by looking at the rich harvest of this book from some distance, using the perspective of comparative law.

Having decided to take a comparative approach, one is confronted with some basic questions: What do existing theories of comparative law have to say about the Chinese legal system? What images of Chinese law do they evoke? Are those theories supported by what I see when looking at 'our' case, i.e., law-making in the Netherlands? By answering these questions I hope to be able to present some useful reflections on both law-making in China as well as on the way comparative law has dealt with China's legal system so far.

Of the many theories of comparative law, I have chosen to concentrate on those which attempt to classify the legal systems of the world into categories or legal families on the basis of one or more criteria. The case of the PRC, in particular its problems concerning law-making, may be used to investigate to what extent it has properly been categorized according to one or more of these theories.

The first theory of comparative law I propose to discuss is the one developed by René David and published in collaboration with John Brierley. In David's view, any satisfactory categorization can only be based upon two criteria: legal technique and ideology, the latter being of primary importance. On the basis of ideology - i.e. the

The author wishes to extend his gratitude to both Martijn Polak and Jianfu Chen for their substantive contributions to and comments on this final chapter. Martijn Polak has shared his knowledge of comparative law and Dutch law-making, while Jianfu Chen has generously added recent information on Chinese law. He also ack include Ger van de Berg on Sovjet law, and Theo Bellekom on comparative constitutional law, both from the Faculty of Law of Leiden University.

215

J. M. Otto et al. (eds), Law-Making in the People's Republic of China, 215-233.

(c) 2000 Kluwer Law International. Printed in the Netherlands. 
philosophical basis or concept of justice underlying the legal system - three legal families are identified. These are the Romano-Germanic Civil law family, the AngloAmerican or Common law family, and the socialist family, which together contain most legal systems of Western Europe, Eastern Europe, North America, Latin America and Australia. The systems of Africa, Asia and the Middle East are brought together in a primarily 'traditional/religious' group of systems, a fourth legal family as it were, which is, according to David, based on '[o]ther conceptions of law and the social order'. This family is then subdivided by region. Chinese law is dealt with in a chapter called 'Laws of the Far East'.'

According to David and Brierley, the Chinese 'people do not see law as a major vehicle for assuring peace and social order'. They even have an 'aversion for law' and a 'traditional antipathy towards the clear-cut forms of legislative statement'. It therefore would not have come as a surprise when, after a short period of operating law on a Soviet based model, Mao rejected law and legality altogether. Efforts at codification were then halted and party directives took the place of law. ${ }^{2}$ Elsewhere the authors put forward the idea that in China '[t]he good citizen must not concern himself with law. (...) Laws may exist to serve as a method of intimidation or as a model; but law is not made with a view to really being applied, as in the West'. ${ }^{3}$ The image thus conveyed reminds me of the 'Marble Boat', a tourist attraction situated on the border of the lake of Beijing's famous Summer Palace. It looks like a real boat, modeled after the famous Mississippi paddle steamers, with French and American-style windows and ornaments. People go aboard, look at it and take pictures of it. But it is a marble boat, it could never sail, and if it tried it would immediately sink. Is this a proper image of China's legal system as I recognize it from the studies of law-making published in this volume?

The second and perhaps most commonly accepted theory is the one proposed by K. Zweigert and H. Kötz, which focuses on the criterion of 'style' of a legal system.' Style as the main criterion is refined to encompass five sub-criteria or elements: (a) historical background and development; (b) predominant and characteristic mode of thought in legal matters; (c) especially distinctive institutions; (d) the kind of legal sources acknowledged and the way they are handled; and (e) ideology. These criteria lead Zweigert and Kötz to make a sixfold distinction between (a) the Romanistic legal family; (b) the Germanic legal family; (c) the Nordic legal family; (d) the AngloAmerican legal family; (e) law in the Far East; and (f) religious legal systems. The PRC was originally put in the group of legal systems that together form 'law in the Far East'. In previous editions it was presented together with the Japanese and other Asian legal systems. But in the 1998 edition the authors have abandoned the Far Eastern legal family: Japan is now seen as more liberal and democratic, and with a western-oriented law, while China, although it has taken 'astonishing steps in the same direction' is still

René David and John E.C. Brierley, Major Legal Systems In the World Today, third edition (London Stevens \& Sons, 1985), pp. 516-546.

Supra note 1, pp. 516, 520, 525-528.

Supra note 1, p. 30. 1998). socialist ${ }^{5}$ Moreover 'it is doubtful whether the tradition of Confucianism still obtain in modern China and Japan'. ${ }^{6}$ Zweigert and Kötz have thus given up classifying the Chinese system in any of their 'families'. However, they end with some cautious suggestions and quotations about the present manifestation of law in China. ${ }^{7}$ These al seem to support the hypothesis that it may take quite some time and a drastic reform of the political system before law in China is actually valued and applied in the way it is done in the west. Awaiting such change, reflecting real progress will, it is suggested, be very slow. Not only has codification itself taken a long time, but the road to actual application and legal certainty is expected to be a very long and winding one. The image evoked seems to be one of steady but very slow progress indeed, and it is in this context that the image of a turtle comes to mind.

The last theory to be discussed here is the one proposed by U. Mattei. ${ }^{8} \mathrm{He}$ arrives at a threefold distinction between legal systems: (a) a predominantly professional legal system, such as is found in most Western countries, (b) a predominantly political law, where the legal system is permeated by political interference, and (c) a mainly traditional legal system, found in countries in which religious or customary rules and institutions are predominant in the legal area. According to Mattei, such categorization is not fixed: on the contrary, legal systems may, at what Mattei calls a macrocomparative level, switch from the rule of professional law to the rule of political law or the rule of traditional law and vice versa. At present, the PRC's legal system would or the rule of traditional law and vice versa. At present, the PRC's legal system would
have to be placed, so Mattei claims, in the category of either the rule of political or the rule of traditional law, given the predominant influences of political (socialist) or traditional (Confucianist) ideology on the development of law. Mattei then firmly chooses to put China in the box of 'traditional' systems. ${ }^{9}$ Legal systems in the families of traditional law and political law are usually not very effective; the rule of law is not celebrated there.

The evolutionist foundations of Mattei's classification are obvious. First, al normative systems start with traditional rules. Next, most young states tend to have an unbalanced political development in which executives and political parties dominate over weak legislatures and weak judiciaries, until the third phase begins. Then, finally, socio-economic progress and democracy grow until they allow for an autonomous system of professional rule, in which the law is firm and strong, and powerful as a dragon, I might say. Is this dragon coming alive in today's China? Mattei has not seen the signs yet, but then, he is an aloof observer, and the contributors to this book have been much closer to the scene, some of them very close indeed.

The three theories and the images they evoke may be tested by looking at the problems of law-making experienced in the PRC. For the sake of clarity, I follow the same grouping of these problems as in the introductory chapter (see Otto and $\mathrm{Li}$ ). I first

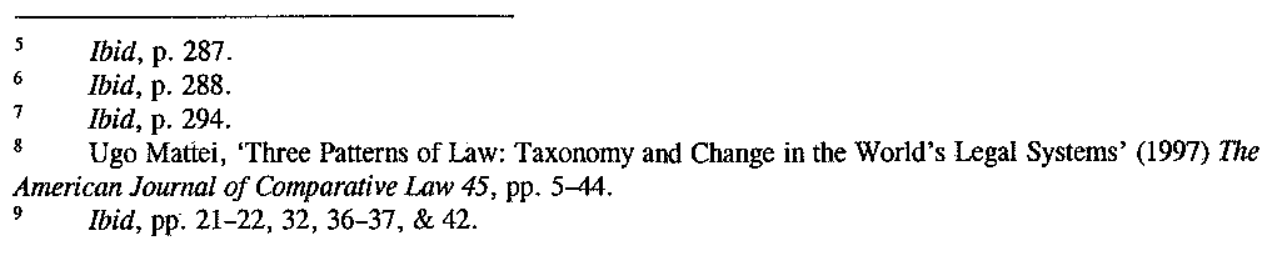


discuss the actors who are engaged in law-making (section 2), their products (section 3 ), the law-making process itself (section 4), and the quality of the products resulting from this law-making (section 5). Next, I pay attention to the question of whether lawmaking does contribute to legal certainty (section 6) before I finally revert to comparative law (section 7). There, I try to determine whether on the basis of this volume there is a relevant legal family of which China could be seen to be a member. I try to discern, in the words of Zweigert and Kötz, a Chinese 'style' of law-making that differs from the styles found in other countries. And finally, I will see whether I can agree with Mattei's observation of which rule of law is actually prevailing in China: traditional, political or professional.

\section{Legislative Actors}

In search of China's legislative actors I have looked first at the surface of the constitutional trias politica. For law-making is an issue which belongs to constitutional law. As A. Chen explains, the Chinese Constitution of 1982 is in many ways similar to the 1954 constitution, which was to a large extent based on Soviet ideas of constitutional law. Therefore many of the constitutional provisions on law-making as well as many provisions of the most important organic laws are distinctively socialist. ${ }^{10}$ Major examples are the role of the Communist Party that directs both society and the state organs, the role of the NPC as the 'supreme organ of state power' in which all legislative power is concentrated, and the role of its Standing Committee. The peculiar positions of the Supreme People's Court and the Supreme People's Procuratorate can also not be understood without reference to the Russian models by which the drafters were inspired. ${ }^{11}$

It is against this background that one should understand the major distinction that is made by Chinese jurists between those actors who make real legislation, such as the NPC and its Standing Committee and Provincial People's Congresses on the one hand, and the makers of government rules (guizhang) such as the ministries and commissions under the State Council, and the regional and local people's governments on the other hand. Chinese constitutional thought has always stressed this difference.

One of the striking features of the edifice of law-making institutions, as explained by Otto and $\mathrm{Li}$ in this volume, is the interpretative power or 'ownership' that law-

For more detailed discussions, see A. Chen, An Introduction to the Legal System of the People's Republic of China (Singapore: Butterworths, 1993), ch. 4; J. Chen, Chinese Law: towards an understanding of Chinese Law, its nature and development (The Hague/London/Boston: Kluwer Law International, 1999), ch. 3. For discussions on historical and comparative background, see John N. Hazard, Communists and Their Law: A Search for the Common Core of the Legal Systems of the Marxian Socialist States (Chicago/London The University of Chicago Press, 1969). For a discussion of the most recent revision of the Chinese Constitution, see J. Chen, 'The Revision of the Constitution in the PRC: Conceptual Evolution of "Socialis with Chinese Characteristics"', (July 1999) 24 China Perspective 66-79. In particular the role of issuing general 'opinions' on laws promulgated in China and the legal effect of
the 'opinions'. making bodies have over the laws they have issued. This provides a fundamental addition to the importance of the NPC, its Standing Committee and the State Council, whilst appearing to involve a reduction in the power of the judiciary, as compared to other legal systems which give wide interpretative powers, or even the main lawmaking function, precisely to the courts. Yet socialist systems have their own solutions for this problem. Rather like in the Russian example, in China at least since 1981 both the Supreme People's Court and the Supreme People's Procuratorate have come to share the highly important function of issuing authoritative 'opinions' which are considered to have legal force. ${ }^{12}$

In spite of constitutional theory the State Council or 'Chinese cabinet' is by far the most powerful state organ in the legislative process. It determines the state policies which in turn largely determine both the timing and the contents of the laws. Its administrative regulations form 'the backbone of the Chinese legal system' ${ }^{13}$ It supervises the ministries and commissions which make most legislative drafts as well as local governments. It prepares most of the national bills before they are sent to the NPC. ${ }^{14}$ It has been delegated powers of national law-making by the NPC, and it has a major resource in the Legislative Affairs Office, which seems to be the real spider in the wide web of Chinese law-making. ${ }^{\text {is }}$

The NPC's constitutional role as the supreme legislative authority may have increased significantly over the last twenty years but it is still limited by both legal, political and practical factors. ${ }^{16}$

Digging further beneath the surface of constitutional form we will discern the real power-holders in the legislative process, notably the massive civil service and the Communist Party cadres. In western countries the civil service has sometimes been called 'the fourth power', a description which would also fit China. The Communist Party's constitutional position also entitles it to be seen as a superpower above the other four. Party cadres and the civil service form the most formidable combined force in each Chinese state activity, including law-making.

In post-Mao China, this power was initially granted by the Resolution of the Standing Committee concerning the Strengthening of Legal Interpretive Work, adopted by the Standing Committee of the NPC on 10 June 1981. This Resolution then is a revised version of the Resolution concerning Legal Interpretation of 1955. In 1997, the Supreme People's Court issued the Several Provisions on Judicial Interpretation and, for the first time, formally declared that its interpretations are to have effect of law. A year earlier, similar provisions were issued by the Supreme People's Procuratorate. For further discussion, see J. Chen, supra is doubtfil whether the Supreme People's Court and the Supreme People's Procuratorate have the constitutional power to do so. Unfortunately, the newly enacted Law on Law-Making (adopted on 15 March 2000) does not deal with this important issue at all.

${ }_{13}$ See Keller and Li Shishi in this volume.

See Li Shishi in this volume.

is Ibid.

See Keller in this volume. For more detailed analyses, see Kevin O'Brien, Reform without Liberalization: China's National People's Congress and the Politics of Institutional Chang (N.Y.: Cambridge University Press, 1990), Murray Scott Tamer, 'How a Bill Becomes a Law in China. Stages and Processes in Law-Making', in Standley B. Lubman, Chinese Legal Reform (Clarendon: Oxford University Press, 1996), pp. 39-64. 
As still some 80 percent of all real legislation, not to mention administrative rulemaking, originates from the desks of civil servants, the main real actors in the production process of Chinese legislation are in effect the law-drafting civil servants of the ministries, commissions and of the provincial and cities' administrations, together with the all-important Legislative Affairs Office under the State Council. ${ }^{\text {" }}$

Through various visits to and interviews with the relevant authorities in China, I am under the impression that the orientation of these actors is often quite professional, technical-legal and pragmatic rather than primarily ideological. Therefore, they constitute nuclei for establishing the rule of professional law in China. I acknowledge however that their room for maneuvering is often limited by political and administrative considerations. ${ }^{18}$ Practice has proved that at this point in time this professionalism is not sufficiently well entrenched as to naturally produce consistent and predictable applications and interpretations of legislation.

The commanding spirit of the Communist Party remains present in all formal lawmaking bodies. Leading party members play dominant roles in the civil service, the courts, the People's Congresses and Standing Committees. Their committees, secretaries, praesidia and chairmen of course keep a firm grip on those matters that are most politically sensitive. Their politico-administrative style of getting things done by policy experiments is the prevailing style of law-making. It is 'general and flexible' and 'prefers the coarse to the fine'. But even in these bodies professionally-oriented jurists are creeping in: the Legislative Affairs Commission of the Standing Committee of the NPC provides a telling example.

In the rearguard of this parade of legislative power-holders, we find a loosely ordered group committed to the development and dissemination of legal knowledge per se: legal scholars, law teachers, law journalists and certain interested citizens. ${ }^{19}$ Since 1979 this group has also contributed to a surprising come-back of law in Chinese universities and media. The age-old history of China as a society in which study, learning and training are considered a valuable asset has certainly helped, in combination with the country's great administrative skills and communist mass-line strategies. As both Zhu Jingwen and Li Buyun suggest, both scholarly academic input as well as citizen's participation are increasingly important forces in the law-making process. A highly important new resource for this group is now the Internet. I cannot illustrate this better than by referring to the websites of the NPC and the People's Daily. On March 15, 2000 almost immediately after the Law on law-making had been approved by the NPC but before it was formally promulgated by the President of the PRC as required by the Chinese Constitution, its full text could be read on PC screen around the country and the world, including, I may say, a PC at our institute in Leiden.

This necessarily short and limited overview of the actors in law-making conveys a picture that is more dynamic than the image of a marble boat or a turtle. In the minds of a significant number of actors, the dragon's rule of professional law is coming into

\section{See Li Shishi and Sun Chao in this volum}

See also Cabestan in this volune.

See Li Buyun, Zhu Jingwen, Sun Chao, Ye Feng in this volume. its own. But these actors are usually kept under control by the party and state leaders, to whom political stability and economic growth are ultimately more important objectives than democracy and lecol certainty. In this respect, however, the judgments of regional and local leaders will often differ from views held at the center. At present the limits of legal progress are constantly being explored and demarcated by hundreds of jurists all over the country - individual actors, who, if mentioned by name, would refute the image of the Chinese law-making machine as the monolithic, faceless apparatus that has so often been pictured.

\section{Legislative Products}

In China's legal literature, a common distinction is made between primary, secondary and tertiary law. The products of the NPC and its Standing Committee are considered primary legislation. Their status is that of the highest of all legislative products. This position derives from the supreme powers of its creators as granted by the Constitution. In this category we find the constitution, the basic laws, the laws and certain decisions by the NPC or its Standing Committee. Nobody except the NPC or its SC may alter, or provide general interpretations of, these laws.

This primary legislation sets the ground-rules for legislation by both the national
Thide general interpretations of, these laws. executive, the State Council, as well as by the regional and local legislatures, i.e. the People's Congresses and their Standing Committees. Their various legislative products are called secondary legislation. The secondary legislation of the State Council must be 'in accold local people's in accordance with' primary 1 congresses should 'not contravene' primary legislation. From these formulas one may learn that in theory more autonomy has been granted to the regional and local legislatures than to the State Council. However, due to the wide powers of NPC delegation to the State Council on the one hand, and to central powers of legislative supervision on the other hand, the reality is quite different.

The primary and secondary legislation together constitute the backbone of the Chinese legislative system and are often considered 'true legislation' by Chinese jurists, notwithstanding the fact that there are still various disputes about the scope and binding force of some of these products. ${ }^{20}$

For the day-to-day users of Chinese law, the flesh covering the backbone consists f a myriad of lower regulations, the so-called tertiary legislation. Again, we can distinguish two parts of tertiary legislation, the central part and the regional and loca part. The central part includes the departmental rules or guizhang, while the regional part. The central part ind rules by the regional and local People's Governments. It has and local part includes rules by the regional and local People's Governments. It has been argued that the main bulk of China's legislation consists of many kinds of lower
regulations - central, regional or local, general or sectoral - promulgated by the widely diffuse institutions of the Chinese state and party. The history of this tertiary legislation goes back to that of the 'normative documents' of communist rule in previous decades.

$20 \quad$ See Otto and $\mathrm{Li}$, and $\mathrm{Li}$ Buyun in this volume. 
Today the legal status of guizhang is still highly problematic. According to Chaoyang liang in the present volume, basically there is a legislative hierarchy according to which normative instruments are based on guizhang, which in turn are based on administrative regulations, which are based on laws. However, the binding force of guizhang and normative instruments in individual cases is often unclear. Ideally, this is to be decided by the courts. ${ }^{21}$

An appraisal of Chinese legislative products must invariably deal with two subjects: the lack of clarity, and the lack of consistency. Let me discuss these one by one.

Many observers indicate the lack of clarity with terms like 'vague', 'broad', 'imprecise', 'unclear'. It could be argued that all this vagueness serves a purpose, i.e. to allow the holders of the power within state and party to adapt and 'interpret' the law in ways that are convenient to the rapidly changing conditions on the one hand, and to their bureaucratic interests on the other. This is not a secret purpose: being 'general and flexible' is an official requirement for law-making. It is the consequence of the prevailing view of law as an expression of Party-led policies, for in China legislative products are firmly chained to policy - they are an expression of policy goals. Thus, as Li Shishi has formulated it: 'Law is the legalization and 'articlization' of policy; and it is made when the time is ripe.' Law, as Keller quotes Li Peng, ${ }^{22}$ is the finalization of the Party line, principles and policies. It needs to reflect current policies and current circumstances. This calls for constant adaptation and flexibility. ${ }^{23}$

Thus the lack of clarity is the price paid for pragmatism in law-making. It conflicts with the ideology of the supremacy of law, which requires, above all, clarity, systematic stability and finality. Various authors observe a cautious move towards a higher degree of precision in legal language.

The problem of vague and broad provisions applies especially to primary legislation. This has created an urgent need for more detailed secondary and tertiary legislation. Secondary legislation has thus become in a sense the most important legislation. As observed by many scholars within and outside China, it has even reduced the importance of primary legislation to the extent that national laws are not essential to the normative governance of any issue, as subordinate regulations are issued in the interim.

21 Articles 79-83 of the Law on Law-making now formally establish an authoritative hierarchy of laws and regulations. However, the new Law neither clarifies the legal status of guizhang nor defines the role of the court in deciding their legal status. It should be pointed out, however, that under Article 7 of the over concrete administrative acts, an applicant may request the reviewing authority to examine the legality of provisions (Guiding) issued by organs of the State Council, governments at and above the county level and provisions (Guiding) issued by organs of the State Council, governments at and above the county level and ${ }_{22}$ their departments, and by township governments.

On this point, see furthér discussions in Pitman B. Potter, The Economic Contract Law of China: Legitimation and Contract Autonomy in the PRC (Seattle/London: University of Washington Press, 1992); and Jianfu Chen (From Administrative Authorisation to Private Law. A Comparative Perspective of the Developing Civil Law in the People's Republic of China. (Dordrecht: Martinus Nijhoff Publishers, 1995), ch.
The fact that NPC laws may be important, but neither decisive nor essential, reflects on the legal system as a whole. The lack of consistency that critics have observed is strongly connected with the fact that NPC laws, although they are formally the primary elements of the legislative system, are in practice not always respected by lower law-makers. Uncertainty about the hierarchical position, the scope, and binding force of certain legislative products is still not exceptional in today's China. ${ }^{24}$ The 'bureaucratic selfishness' of departmental rules has become proverbial, and the 'bureaucratic selfishness' of departmental rules has
cascades of departmental guizhang are hardly controllable.

In the meantime, regional and local People's Congresses and People's Governments are diligently legislating thousands and thousands of regulations and rules on social and economic affairs that concern their citizenry. The size of the country and the tragic history of local warfare in more or less autonomous regions, have caused a strong perception of the need for central control. In spite of worldwide tendencies for strong perception of the need for central control. In spite of worldwide tendencies for
democratization and decentralization, it seems that for all major subject areas it is the central government that has the power to make laws. However, according to Sun Chao, law-making at the local level is very important and often underestimated by outsiders. ${ }^{25}$ While national legislation is often lagging behind and vague, local law-making, notably in a city like Shanghai, seems to be vibrant and vital. Uncertainty about legislative competence, priorities and supervision gives a lot of leeway to powerful regional and local lawmakers. Their legislative behavior has at times been so autonomous that one contributor even speaks of a 'disguised federalism'. ${ }^{26}$ The inconsistencies and uncertainties about legislative relations between the center and the regions have worried many observers on both sides. It is one of the key issues in the new Law on LawMaking, and it was also one of the causes of its delay.

This law by its own contents and uniqueness - no major legal system that I know of possesses a Law on Law-making - shows that China's legislative products are definitely not always 'copies' from the west as some commentators have suggested. Looking at the whole body and nature - socialist, civil, or common law - of China's major pieces of legislation, as A. Chen has done in this volume, the comparative foreign scholar comes across many familiar concepts and legal flavors: Russian, Taiwanese, German, French, but also American and English, both directly or through international law. ${ }^{27}$ The older part of public law has a number of Soviet-like features but most of the private and administrative law clearly follows the patterns of Civil law and its style of codification. Therefore 'it may be expected that the Civil law tradition will be the dominant influence in the development of Chinese law in the foreseeable

24 See supra note 21.
25 See further infra note 26.

26 See Keller in this volume. Ironically, as pointed out by Jianfu Chen and Lijian Hong, since 1992 when the establishment of a 'socialist market economy' was decided as the new direction for economic reform, there has been an unmistakable trend towards re-centralization of law-making in the name of integrity of legal system and uniformity of policy practice. See Jianfu Chen \& Lijian Hong, Local China Business Law Guide, Sydney: CCH International, loose-leaf service, Part I.

See Jianfu Chen, 'Internationalization of Civil and Commercial Law in the PRC', in Kanishka Jayasuriya (ed), Law, Capitalism and Power in Asia (London: Routledge, 1999), at pp. 69-94; and Wang Guiguo, 'Economic Integration in Quest of Law', (1995) 29 Journal of World Trade 5. 
future', ${ }^{28}$ although, because of the international leadership of the US and the incorporation of Hong Kong, the "potential for common law influence cannot be underestimated' ${ }^{29}$ Having searched for, absorbed and digested so many influences, the Chinese legal system does not fit into any particular family; it is perhaps best described as Chinese. On the whole, judging from its legislative products, the Chinese approach to law-making has been rather eclectic and pragmatic. This approach is not typical for China only, however. Actually, it is common to a group of developing countries that have sufficient numbers of self-conscious and skilled jurists not to be bound to the former colonizer's legal system, or any existing system for that matter. India, Indonesia, Mexico and Egypt could be seen as other members of this 'pragmatic development-oriented group'. They realize that in some respects civil law and common law are coming closer, and they want only what is best for them. Still, the foreign country or institution that sponsors a legislative project or a training course under a technical assistance scheme may try to propose their own home-grown solution to their Chinese counterparts. But the expertise among Chinese jurists has increased too rapidly to consume much neo-colonial 'imposition' of law.

\section{The Process of Law-making}

The legislative process in China is firmly based upon a set of legally established procedures. The chapters of this book refer to at least twenty different legislative products, which are wholly or partially devoted to law-making. They include:

- the Constitution (Articles 62, 67, 89, 90, 100, 107, 116);

- the organic laws concerning the NPC, the State Council, the Local People's Congresses and the Local People's Governments, Regional Minority Autonomy;

- the Basic Laws on the Special Administrative Regions of Hong Kong and Macao;

- the SCNPC Resolution on Strengthening the Work of Interpreting the Law of 1981;

- the Decisions by the SCNPC to delegate legislative power to the State Council of 1983 and 1984; a similar Decision by the NPC itself of 1985; the Decisions of the 1980 s and 1990s on granting legislative powers to Special Economic Zones);

- the Decisions concerning the Procedures of the NPC of 1989;

- various administrative regulations such as the Provisional Regulations on the Procedures for the Enactment of Administrative Regulations of 1987; the Circular on Improving the Promulgation of Administrative Regulations and the Decisions Concerning the Registration of Regulations and Rules of 1990; and

- dozens of local regulations of the 1980 s and 1990s on 'Procedures for Formulating Local Regulations'.

Beside such pieces of legislation on law-making, legislative plans are mentioned in several chapters, as well as a number of normative party documents. Added to this long list is the newly enacted Law on Law-Making of 2000 .

28 See A. Chen in this volume.
In spite of this wide coverage of law-making by laws, the legislative process is still plagued by serious problems that are discussed by several contributors. These problems include problems of designation and recognizability, competence, priority and supervision (Otto and Li), the delay in the making of NPC laws (Keller), the tendency of departments to legislate for their own power rather than for citizens' rights and the rule of law (Li Shishi), the status of guizhang and control over guizhang (Jiang), the lack of participation (Zhu) and the division of powers between center and regions (Sun Chao). All of these problems are also mentioned in Li Buyun's contribution about the Law on Law-making. ${ }^{30}$

Otto and $\mathrm{Li}$ have distinguished eight stages in the process of law-making, namely (i) agenda-setting; (ii) drafting; (iii) wide discussion; (iv) interdepartmental consultation; (v) political (party) leaders' approval 'in principle'; (vi) decision-making in people's congresses; (vii) publication and registration, and (viii) implementation in people's congresses; (vii) publication and registration, and (viii) implementation
through executive regulations. This is based on earlier work by Scott Tanner who distinguished five different phases. ${ }^{31}$

The various chapters have increased our knowledge and understanding of each of these stages, and contributed to several ongoing debates about the process of lawmaking. Through these we now understand that initiatives to bring certain drafts onto the agenda can come from many different sources now. In the national agenda-setting process, however, the Legislative Affairs Office has come to play a vital role, through - its powers in legislative planning. Since 1998, the LAO has had the initiative in putting forward national draft legislation plans to the key ministries. Even though such plans need the final approval of the State Council, the LAO plays a key role, from the beginning to the end. Also, in its legislative planning the NPC must take into account the legislative program of the State Council as prepared by the LAO. Departments also make their own legislative plans for guizhang, which are coordinated by their Legal Affairs units.

It also seems that in the law-making process participation from different institutions has become common. Several authors such as Sun Chao, Zhu Jingwen, L Buyun, Chaoyang Jiang and Ye Feng have discussed people's participation. According to Sun and Jiang, there are clear signs of a growing practice of soliciting opinions from the public when departmental and local regulations are prepared which have a direct impact on individuals. Li Buyun and Zhu plead for a legal obligation for law-makers to do so.

Several authors have discussed institutional participation by legislatures. They have stated that the deliberation in the People's Congresses has become more extensive and significant, granting the delegates more powers and more time to examine and review law bills. Procedures were changed to that end, and the impact on the legislation itself is now significant, both at national as well as regional levels. Congress work is now often well-prepared by the work of special committees and professional staff, who scrutinize drafts and exercise at least some degree of control over the government's Fo a systematic treatment of these problems, see J. Chen, supra note 10, ch. 4.
Tanner, supra note 16. 
proposals. At the central level the NPC has initiated various consultative drafts, and organized considerable expertise in its staff offices, notably in the Legislative Affairs Commission of the Standing Committee. Yet in this process delegates of the People's Congresses, though their powers are somewhat on the increase, can still not make major alterations unless they get the green light from state and party leaders. Sometimes they have to wait. In those cases the People's Congresses and their standing committees may turn into a place for endless deliberations and repetitions rather than a place for concerted law-making. Considering the pragmatically piecemeal approach and the diversity of bureaucratic interests, one often notices a time during stages (iv) to (vi) in which no law can actually be passed before there is consensus about rightness from a policy perspective. The leadership will therefore often only reach consensus when policy experiments have proved that a certain policy is valid, and then it can be 'legalized and articlized' into law, in the words of $\mathrm{Li}$ Shishi. While lengthy consultations and deliberations about law-making take place, all kinds of interim solutions are sought to lend some kind of legality to administrative actions. When interim provisions are there, the sense of urgency in the real law-making process gets lost, and no mechanisms are available to speed up the process. Here one is reminded of the image of the turtle.

So far comparative studies of Chinese law have seldom revealed that in the legislative process the civil service and the party are no monolithic entities. There is a great deal of bureaucratic pluralism. Chaoyang Jiang and Li Shishi draw a picture of well-organized examinations and deliberations within the bureaucracy as a precondition to reaching balanced conclusions on legislative proposals.

One important distinction should be made, namely that between the legal offices and the policy directorates. In the ministries and commissions, in stage (ii) of drafting, most of the national laws and lower regulations are prepared by the technical policy experts, while the Legal Affairs units scrutinize and evaluate the legal and general merits of proposals. In the Executive Meeting of each ministry, both the policy experts and the legal experts are called in to present their views to the leadership.

At a higher level, the same happens in the Executive Meeting of the State Council, where representatives from the Legislative Affairs Office present their views on legal quality while representatives from the respective ministry or commission explain the proposal from a policy perspective. Each proposed piece of legislation which goes to the State Council is first scrutinized by the LAO which prepares an evaluation report 'from the perspective of the overall work' of the State Council for its Executive Meeting. This review by the LAO, which accompanies not only administrative regulations and departmental rules but also draft bills for the NPC, is in fact a very important stage that could also be added to our empirical typology of stages.

\section{Technical Quality of Legislation}

Legislators in many countries are challenged to improve the technical quality of their products, i.e., legislation. The PRC is no exception to this, as is evidenced throughout the chapters of this book. Indeed, the need to improve the quality of Chinese legislation, both at the central and at the local level, is widely recognized. There is, however, less agreement on what exactly constitutes 'good legislation'. Is it possible for however, less agreement on what exactly constitutes 'good legislation'. Is it possible for
me to identify certain criteria to distinguish good from inadequate legislation? At this me to identify certain criteria to distinguish good from inadequate legislation? At this
point a small sidestep to the Netherlands may be useful. A few years ago, the Dutch Ministry of Justice published a white paper called 'Legislation in Perspective ${ }^{32}$, in which quality criteria for government action via legislation were formulated. These criteria can be classified as follows: (a) lawfulness and the realization of the principles of justice, (b) effectiveness and efficiency, (c) subsidiarity and proportionality, (d) feasibility and enforceability, (e) coordination, and (f) simplicity, clarity and accessibility. These requirements, according to the white paper, are important, first, with regard to the question of whether legislation is truly necessary; subsequently, in determining the contents of the eventual law; and finally, in the retrospective evaluation of the law. Moreover, the quality criteria must be kept in mind throughout the various stages of the legislative process by all participants in this process.

It would be an interesting exercise to first compare these criteria to the provisions - of the draft Law on Law-making discussed by Li Buyun in this book and, subsequently, to apply the Dutch criteria to the various Chinese laws and draft laws discussed in this book, particularly in Part III, and to see to how Chinese legislation would emerge from this scrutiny. This is, of course, not to say that 'good legislation' is exactly the same in China as it is in the Netherlands, but the comparison is interesting enough. Here there China as it is in the Netherlands, but the comparison is interesting
is only room for some very superficial analysis of this question.

Comparing the Dutch criteria with the Chinese draft Law on Law-making reveals some remarkable similarities. For instance, both recognize the need to coordinate the work of several ministries and government agencies with each other in order to avoid either gaps or overlapping in the legislation. In fact, the Legislative Affairs Office of the State Council, described by Li Shishi, fulfills this role of coordination between the many institutions engaged in the law-making process. Another similarity has to do with many institutions engaged in the law-making process. Another similarity has to do with
the need to ensure the accessibility of the law, which in practice means accessibility of the need to ensure the accessibility of the law, which in practice means accessibility of
a dense maze of laws, regulations and other legal norms. ${ }^{33}$ Publication of legislation is only a first step towards ensuring this accessibility and governments are increasingly often asked to actively distribute, or even 'market', their legislative products.

Particularly in Li Buyun's contribution one can discern many similarities between he Dutch criteria and the Chinese draft Law on Law-making. For example, the Dutch

Ministry of Justice, Legislation in Perspective: A policy plan for the further development and implementation of the general legislative policy, aimed at improving the constitutional and administrative quality of goverriment policy, transted from Dutch (Den Haag: 1991).

Timely publication of laws and regulations is now made a legal requirement in the Law on Lawmaking. 
criterion (a), lawfulness and the realization of the principles of justice, has a direct link to what $\mathrm{Li}$ Buyun describes under the heading of legislative authority: which institution may or must act at a certain stage of the law-making process. This is what one might call the dimension of constitutionality; laws should be made by institutions constitutionally charged with the task of law-making.

At an even more concrete level, an interesting similarity exists between some of the Dutch criteria and the five standard questions described by Li Shishi: subsidiarity and proportionality as well as feasibility and enforceability function as criteria in both the Netherlands and the PRC for reviewing the technical quality of legislation.

Applying the Dutch criteria to the Chinese laws and draft laws discussed in the case studies of Part III would probably reveal many deficiencies, as is the case with many Dutch laws if closely scrutinized. In fact, Ye Feng's discussion of the previous Criminal Law is the equivalent of a painstaking review of a piece of legislation which clearly fell short of many of the Dutch criteria for good legislation, a conclusion which the government of the PRC had also reached on similar grounds.

If one were to use this section's excursion into the realm of the technical quality of legislation as a tool to analyze the various theories of comparative law discussed in the first paragraph (in other words: does that paragraph provide us with something useful to add to comparative law theory?), I would dare to draw the conclusion that law-making in the PRC is on the road towards becoming more and more professionalized, towards becoming a 'professional law', to borrow Mattei's terminology. Like the Dutch legislator and legislators in other Western countries, a significant number of Chinese legislative drafters, particularly at the central level, are concerned about the technical quality of the legislation, and efforts are undertaken to develop and implement standards to ensure that every piece of law qualifies as good legislation. This means that law-making is recognized as a craft, for which skilled craftsmen are needed, working according to certain protocols. The involvement of craftsmen, i.e., professional lawyers, and protocols, invigorates the relative autonomy of the lawmaking process vis-à-vis the political arena, thereby diminishing to some extent the possibilities for what Mattei would call 'political law'. This leads us to conclude that even a fairly technical-legal attempt to improve the quality of legislation in the PRC, if successful in a strictly technical sense, will have a direct, albeit modest, influence on the development of a professionalized and depoliticized law in the PRC, and will thus contribute to the rule of law.

All this sounds rather optimistic. However, at present, there is, as observed by many, a severe lack of experienced, skilled legislators, an observation shared by the 15th Session of the National Congress of the CCP in 1997, which proposed 'to strengthen legislation and to improve its quality'. This pessimistic view is also shared by Li Shishi, himself an important contributor to the legislative process. Thus, it is clear that the PRC has a long way to go before the technical quality of its legislation will be beyond criticism at home or abroad.

\section{Legal Certainty and the Rule of Law}

In the introductory chapter, Otto and $\mathrm{Li}$ have stated that good legislation, though very important, is only the first step on the long road to legal certainty. However, most authors in this book have pointed out more or less serious flaws in the legislative framework. The most fundamental point of criticism is that China's flexible, pragmatic framework. The most fundamental point of criticism is that China's flexible, pragmatic
approach to legal reform has favored policy over legal certainty to the extent that legislative hierarchy can be set aside whenever high officials want to do so. In Keller's words '[1]aw in China does not function as a fundamental source of certainty and predictability in social, commercial or administrative relationships (...)', and the legal institutions and legal thought 'are not yet well enough established to produce consistent or predictable patterns of legal interpretations'. In this respect David may still be right when maintaining that law in China is even now regarded as 'an instrument of arbitrary action rather than the symbol of justice'.

These descriptions would have fitted the legal systems of most developing countries. But the problem of legal uncertainty in China has some outstanding features.

In the first place, its root cause is the leadership of the Communist Party with its ideology, its tradition of treating law as inferior to policy, and its institutional power bases in the state administration, the people's congresses, the judiciary, and other places. This leadership is laid down in the preamble of the Constitution, ${ }^{34}$ and it is also a political reality. Over time, Chinese legal thought and theory have adopted and developed concepts that underpin and justify the rule of party policy over and above the rule of law. This lends the problem a much sharper and more explicit focus than in most other developing countries, even if they also have one-party or dominant-party most
rule.

In the second place, the speed, the zeal and diligence, and the scientific and systematic approach with which Chinese jurists since 1978 have reconstructed legislative system, seemingly on the assumption that a rule of law is about to arrive in China are quite remarkable when compared with most other developing countries. This can be illustrated not only by the output and systematic publication of national, sectoral and local legislation, but also by the many processes of scrutinizing legislative drafts and local legislation, but also by the many processes of scrutinizing legislative drafts by the concerted efforts to improve it, most spectacularly shown by the drive for the Law on Law-making. ${ }^{35}$ In most other developing countries the failures of the legal system have so much become a fact of life that efforts at improvement often make little headway and are frequently met with sceptcism because of the lack of political and administrative will, resources, skills and proper information systems.

For the first time, the Law on Law-making (Article 3) now incorporates the Four Fundamenta Principles (among them the leadership of Communist Party) as a legal provision, rather than a politica statement in the Preamble of the Constitution.

is Another interesting and telling example is in the area of administrative law-making. See Pittman B. Potter, 'Editor's Introduction', (no. 3, 1991) Chinese Law and Government (a special issue). 
The relationship between these two features of legal uncertainty in China is a dialectic one, and their interaction has some of the features of a protracted struggle for legal certainty. Its protagonists, the jurists, are relatively weak players in the arena of politics and policies, which is dominated by those high party, state and army officials who play the power games that keep the country together and relatively stable and secure, and by the technocrats whose expert opinions shape state social and economic policies. To reach their objective of the rule of law the newcomers have to do a lot of bureaucratic infighting, in all the institutions involved. Gradually, they have seeped into law-making institutions, people's congresses, their staffs, in special committees, and in state administration. But building up strongholds and forging coalitions takes time. ${ }^{36}$ So far, the machinery is not yet working well.

Moreover, as this book shows, it is not at all easy to distinguish all the parties in this arena, and to see who collaborates and who fights one another. While observers applauded the NPC amendment to the Chinese Constitution of 1999 for including the principle of the rule of law, the NPC's action on another battlefront, when it quashed a decision of Hong Kong's Supreme Court, was deplored.

Taking a longer-term perspective, as Jianfu Chen has done in his chapter, it must be acknowledged that in spite of all present shortcomings, the move since 1978 towards greater legal certainty in China is spasmodic but unmistakable.

\section{Back to Comparative Law}

Has comparative law been able to classify the Chinese legal system properly? Do the comparative law theories which I selected provide us with important insights? Are they supported by what we have seen of law-making? Do they evoke correct images of reality?

David's classification and description of the family of 'Laws of the Far East' and of China's law in particular are not supported by the contributions to this book. They are too historical, too static and too one-sided. Law-making in China shows more dynamics than the 'marble boat'.

As long as we keep trying to classify China into the one and only 'correct' family, I will remain unconvinced. As J. Chen and A. Chen both show, legislation in China in general is not based upon one coherent systematic model, but occurs rather on an ad $h o c$ basis, absorbing elements from all relevant systems and experiences, irrespective of whether these are Chinese or non-Chinese, sino-marxist or western-capitalist, and civil law or common law, or even Islamic or traditional in origin. Any piece that can be useful, will be used. This legislative approach is officially endorsed by Deng Xiaoping's famous expression that one has to cross the river by feeling for the stones.

While China's system is officially announced as having 'Chinese characteristics', in classification it can only be seen as hybrid or mixed, i.e. basically Civil-socialist, but with some Anglo-American and free market characteristics.
In this respect China is a prime example of the global family of developing countries which consumes all kinds of legal food without a preconceived preference for France, Germany, Japan, USA, Britain or, as it happens, even the Netherlands. China's posture in international relations and its self-assurance make it a natural leader in this 'family'.

Zweigert and Kötz have also worked with the system of classification in families. We endorse their recent abandoning of the 'family of the Far East' and their subsequent treatment of China as a system of its own. Besides, they have enriched the theory of comparative law with the criterion of 'style', which in their view is the appropriate overall notion to compare and classify legal families.

When setting up the conference, we invited several contributors to concentrate on the question of whether there is a specifically Chinese style. Looking back we realize that we have actually asked them to focus on different 'elements of style'. The various contributions to this book have clearly shown the importance of (a) historical development (Jianfu Chen, Sun Chao); (b) mode of thought (Albert Chen, Li Buyun); (c) distinctive institutions (Perry Keller, Li Shishi, Chaoyang Jiang, Sun Chao, Zhu Jingwen; (d) sources of law and their use (Albert Chen, Otto and Li); and (e) ideology (Von Senger, Jianfu Chen).

As one might expect, the contributors responded quite differently to our question. Thus, where Von Senger took it upon himself to analyze the relationship between - ideology and law-making in China, he could not escape the conclusion that Communist ideology and CPC power-holders have a very tight grip on Chinese law and lawmaking, a phenomenon which distinguishes the PRC legal system from many other legal systems. From this perspective, China still fits well into the socialist family, and it rests under what Mattei would call the rule of political law. I may add that China's state ideology is not only that of communism, it is also an ideology of development. ${ }^{37}$

In A. Chen's attempt to classify Chinese law into the legal families of the world,
In not only that of communism, it is also an ideology of development. he focusses rather on other elements of style, looking at the mode of thought, and the sources of law. He demonstrates many similarities, notably with civil law systems, and significant remnants of socialist law.

J. Chen's contribution deals with yet another element of style, i.e. history. He describes a 'full circle', which started in the late $19^{\text {th }}$ century when the German Civil Code happened to be the latest model available to legislators around the world. It had a profound effect in East Asia, directly in Japan, and later Taiwan, and indirectly in the PRC, placing it in the family of Civil Law. With the rise of Marxist ideology during the larger part of the 20th century, a constant flow of ideological, institutional and legal transplants poured from the former Soviet Union into China. The Soviet system, while having many socialist characteristics, was in its legal-technical doctrines closer to the Civil law system than to the common law, and thus belonged to some extent within the republican heritage. Even today its effects cannot be eliminated with the speed with which the Berlin Wall was dismantled in 1989. In the first decades after World War II 37 Ferrel Heady, Public Administration, a Comparative Perspective (New York: Marcel Dekker, 1996),
pp. 291-294. 
China was able to fence itself off from the Americanization of law that has so much influenced the rest of the world, both through international law and through many national laws around the world. Today, the impact of American legal concepts and models, through training programs, through the newly acceded UN Human Rights Covenants, through international commercial law practices, can no longer be avoided. So, history tells a multi-layered story of law-making and law.

If still challenged to capture the characteristics of a specifically Chinese "style of law-making', I would use the following terms: engineered, development-oriented, eclectic, pragmatic and piecemeal. Chinese law-making is deliberately planned and controlled. Even if ideology seems to disappear from private law, such disappearance is engineered with precision. Freedom of contract, for example, has deliberately not been selected as a leading principle in the newly enacted Contract Law of 1998. The style of law-making is oriented towards several development goals at the same time, stability and economic growth being the leading ones. Many contributors have demonstrated its practical pragmatism and eclecticism. Finally, the 'piecemeal' approach not only refers to the (a) gradual, (b) decentralized, and (c) cautious way in which many specific laws are actually made, a phenomenon described by Otto and $\mathrm{Li}$, but also to the attitude law-making in general which the Chinese legal system seems to have adopted.

To gain a closer understanding of law-making in general as well as of more detailed fields of China's law, the elements of style formulated by Zweigert and Kötz have been useful for the descriptions and analyses in this book. Applying them in specific research inevitably leads to a broad if not exhaustive description of historical events, of examples of legal reasoning, of institutions in a comparative perspective, of a wide variety of sources, including legislation and case law, and ideology. In other words, applying these style elements as research tools practically leads to writing an introduction to Chinese law. Perhaps that is the only satisfactory way to go about any legal system. But we acknowledge that many foreign scholars and practitioners with a comparative law perspective are looking in the first place for brief overviews of structures and eye-openers.

For them application of Mattei's concepts of the rule of professional law, of political law, and of traditional law, and of macro-comparative revolutions that mark the transition from one rule to another, may be quite helpful. I do not refer here to Mattei's positioning of China as a country ruled by traditional law, which I do not support. This book gives us no indication that the tradition of Confucianism is still dominating law-making in any direct way, even if I acknowledge that there may be few signs of the rule of traditional law in the countryside. I would prefer to put China in the 'rule of political law' category. Most contributions to this book certainly confirm what Mattei has called the hegemony of political law in China. Some reveal signs of the struggle to spark off a macro-comparative revolution that will establish the rule of professional law. This book has shown that quite a number of Chinese jurists involved in law-making have been acting as piecemeal revolutionaries, hoping to unleash the dragon. Their performance and productivity do not warrant the image of the marble boat. They may rather be seen as the inner parts, the nerves and muscles of a turtle, more alert, active and complex than would appear from outward appearances.
Whatever image is used, the proof of the legislative pudding will remain in its eating. A thorough analysis of the 'implementation of law' in China is, therefore, my next academic project. The immense proportions of this problem do not deter me. It has been too rewarding to study and report on the genesis of the rule of law in the biggest country of our globe. 